\title{
Applying Reciprocal Questioning (ReQuest) to Improve Students' Critical Reading Ability
}

\author{
Reni Sapitri *', Teguh Satria Amin ${ }^{2}$ \\ I, 2 Universitas Muslim Nusantara Al-wasliyah \\ renisafitriharahap@gmail.com
}

\begin{abstract}
The objective of the research was to investigate the improvement of critical reading skills in reading by the English students through reciprocal questioning (ReQuest). The respondents consisted of 25 students from the VII grade in 2017/2018 academic year. The data were collected through reading tests, observation, and interview. The result indicated that the application of reciprocal questioning strategy significantly improve the critical reading ability of the students as reflected in pre-test and post-test in cycle I and cycle 2: 9.8; 16.04; and 17.64. The findings were supported by the respondents' positive attitudes as reflected in the interviews.
\end{abstract}

Keywords: Reciprocal Questioning; ReQuest; Critical Reading Skills

\section{Introduction}

One of the aims in English teaching process is able to understand an English written text in term of understanding, solving problems and communication. Reading as one of the skills encourages the readers to think critically in understanding the texts comprehensively without concerning on the written text itself. In the level of university specifically English education major, the aims of language learning is a mean of communication. It encourages the students to be able to understand the language concept in form of writing of various topics, explain the relationship and apply it by transforming the information or ideas with their own language.

Concerning the researches on students' ability as foreign language learners in reading had conducted by Vacca, Vacca, \& Miraz (20II). They stated that the problems found by the teachers in teaching reading for the students are interacting with the text while they are reading. The students find it difficult how to create good questions related to their reading text and how to differentiate the questions which has low level information or the questions which need analysis, evaluation and synthesis to find the answers.

Lika (2017) explained that many findings found that the students give chance to practice their understanding strategy but they are not taught the strategy and its application. Furthermore, it is necessary to encourage the future teachers to acquire the ability to teach the students about the strategy and apply it in reading the texts which is reflected through their critical reading ability. Therefore, the critical reading ability is a skill which is necessary to acquire by the students.

In improving the students' ability in understanding an English text especially scientific text beyond their background knowledge, it needs a strategy to comprehend a text and transfer the ideas of the text with their words. The strategy should be activated the students' process and interaction with the texts. One of the strategies which can be applied is 
reciprocal questioning (ReQuest), it helps the students to understand the text and to think critically. Furthermore, Reciprocal Questioning (ReQuest) strategy is believed can help the students to train their metacognitive thinking, to find the main ideas and to increase their curiosity in finding the answers of their own questions. Pressley in (Muijselaar Te al., 2017) states that good understandings toward a text emerges when the readers can predict the texts, give questions while reading, understand the texts and summarize what they have read.

\section{Method}

The research was conducted in two cycles of action research ranged from March to June 2018 at UMN Al-wasliyah University majoring in English department. Classroom action research is done in order to solve the problems in the teaching learning process and to improve the students teaching and learning process in the classroom Kemmis (in Nunan, 1992:95). The research based on the real classroom problem, the researcher collaborates with the English lecturer as partner and applies reciprocal questioning (ReQuest) to solve the problem. The implementation of action research uses the spiral activity, which consists of planning, acting/implementing, observing and reflecting (Hopkins, 1992:22).

\section{Results}

The result of the pre-cycle research was obtained from the result of the researcher's observation of the students before they taught through reciprocal questioning strategy. The students were passive, shy and they felt frustrated in expressing their opinion during discussing one of the reading material. The data of the students' result on pre-test could be seen in the table below.

Table I. The Students' Score in Pre-Test

\begin{tabular}{llrr}
\hline Range Score/Band & Category & Frequency & Percentage \\
\hline 5 & Modest user & $\mathrm{I}$ & $4 \%$ \\
4.5 & & 8 & $32 \%$ \\
4 & Limited user & 4 & $16 \%$ \\
3.5 & & 8 & $32 \%$ \\
3 & & 3 & $12 \%$ \\
2.5 & Extremely Limited user & 1 & $4 \%$ \\
\hline Total & Intermittent user & 25 & $100 \%$ \\
\hline
\end{tabular}

The range of the score in IELTS reading test is $0-9$. Based on the data in the table I above, it can be seen that the majority of the students achieved low band scores in reading comprehension. There were no students achieved above band 5. Furthermore, only one student among 25 (4\%) got band 5 and more students who got band score below 4.5 and still there was one student achieved below band 3. In addition, based on the researcher's observation or notes, it was found that many students had low ability in understanding academic English text.

As a consequence, the researcher made plans, efforts and activities to be done in the first cycle, in order to increase the students' reading comprehension. The problem that the researcher would like to solve was to increase the students' critical thinking in reading comprehension by applying reciprocal questioning in teaching reading. 


\section{Report Cycle I}

\section{Planning}

Based on the data in table $I$ and during the observation while teaching and learning processes at UMN Al-wasliyah majoring in English, it was found that most of the participants were 'poor' in applying reading strategy. They were lazy to read a long academic passage, felt bored and unable to answer the questions correctly. Therefore, it encouraged the researcher to make an improvement in the process of learning reading. The preparation of the action plan included: Implementing reciprocal questioning strategy in teaching reading, preparing some reading materials related to the students' real life and experience, preparing lesson plans as a guidance of teaching done in action, preparing field notes form to ease the researcher as the teacher and the collaborative teacher in observing teaching learning process.

\section{Acting}

The implementation of the action plans in the first cycle was done for 3 weeks. The teacher presented the instructions for 2 times in a week. In teaching reading, the researcher divided the time given into three sessions that is pre-reading, whilst reading and postreading. At the pre-reading, most of the activities were derived from reciprocal questioning strategy because pre-reading is aimed to stimulate students' expectations and interests. At pre-reading also, the researcher prepared the students with sufficient key words through questioning activities derived from reciprocal.

At the first meeting, the researcher started reading activities. The researcher taught the students that they were going to read an academic text about "stress of workplace" which material was taken from the compilation of IELTS reading test. Before they were asked to read carefully, the researcher asked students to make predictions about what information they might get after reading the text. The students were also asked to create their own questions based on the heading, why the workers stresses are and what are they stresses. Then the students were asked to read to the whole text and match their prediction. After that, a small question and answer discussion about the text was held in the class.

At the second meeting in cycle I, the teacher started the lesson by introducing topic of reading material for that day that was about 'going bananas'. Before reading the whole passage, the researcher asked students to make predictions about the content of the passage. Before that, the researcher introduces some keywords to help them understand the text. After the students read the title and headings of the passage, the researcher asked students to discuss with their classmate about which predictions were true and which were not. After that, the teacher asked students to answer the questions in pair based on the information from the passage. On the other hand, the students were given exercises related to the questions and responses which were adopted from IELTS questions in reading part. The students' answers were then being discussed.

At the following meeting the first post-test was held. The test lasted for 60 minutes. The test questions were adopted from IELTS test compilation.

Table 2. Students' Post-Test Scores Category of Cycle I

\begin{tabular}{llrr}
\hline Range Score/Band & Category & Frequency & Percentage \\
\hline 5.5 & & 4 & $16 \%$ \\
5 & Modest user & 14 & $56 \%$ \\
4.5 & & 5 & $20 \%$ \\
4 & Limited user & 2 & $8 \%$ \\
\hline
\end{tabular}




\begin{tabular}{llll}
\hline Range Score/Band & Category & Frequency & Percentage \\
\hline 3.5 & Extremely Limited user & & \\
3 & Intermittent user & & \\
2.5 & & & \\
\hline Total & & 25 & $100 \%$ \\
\hline
\end{tabular}

Table 2 exposes four students ( $16 \%$ ) got band 5.5; fourteen (56\%) achieved band 5 and two students (8\%) achieved band 4 . In addition, it can be seen that the students' average score in test 2 is 16.04 . It indicated that teaching reading by applying reciprocal questioning strategy can improve the students' reading comprehension.

\section{Observing}

In every meeting, the observation was done by the researcher and collaborative researcher. The results of observation which were in the form of field notes were then analyzed and described in details in the findings of cycle I.

\section{Reflecting}

After collecting the data, the researcher discussed the data with the collaborative researcher. In this case, after analyzing the result of field notes, interview and reading comprehension test, the researcher and the collaborative teacher worked together in order to see how far the application of reciprocal questioning strategy can improve the students' reading comprehension. The result of field notes, interview and test described that not all students got significant progress, the researcher and collaborative researcher decided to continue the action to the second cycle.

\section{Report Cycle II}

\section{Planning}

The second cycle was conducted to solve the problem in the first cycle. Based on the reflection results in cycle I, the researcher made some changes to achieve better plan to scaffold the students to be critical readers. The researcher prepared to use selected topics of English academic passage and encouraged the students to ask questions which might discuss in the passage. Then the researcher designed a lesson plan, selected the passage based on the students' ability and discussed the passage.

\section{Acting}

During the implementation of the actions in cycle 2, the students' participation was level up because the activities before and during reading encouraged the students to express their opinion/ questions toward the passage given. They were more enthusiastic than in the previous meeting.

Table 3. Students' Post-Test Scores Category of Cycle 2

\begin{tabular}{llrr}
\hline Range Score/Band & Category & Frequency & Percentage \\
\hline 6 & Competent user & 2 & $8 \%$ \\
5.5 & & 4 & $16 \%$ \\
5 & Modest user & 14 & $56 \%$ \\
4.5 & & 5 & $20 \%$ \\
4 & Limited user & & \\
3.5 & & & \\
3 & & & \\
2.5 & Extremely Limited user & & \\
\hline Total & Intermittent user & 25 & $100 \%$ \\
\hline
\end{tabular}




\section{Observing}

During the implementation of the actions in Cycle 2, the observer rolled to observe the teaching learning process and the students' critical questions toward the passage. The students' participation in expressing opinions and forming critical questions was level up. They were more confidence and enthusiastic than in the previous meeting. Furthermore, based on the interview conducted after the test in cycle I conducted, most of the students stated that the strategy applied in ReQuest helped them to think critically and understand the passage. They argued that they got higher score in reading tests and it challenged them to be more critical in reading an academic passage.

\section{Reflecting}

Based on the figure above, it can be seen that the students' average score increased within test $I$ and test 2 . Meanwhile the scores increased more within cycle 2 . The students got significant progress in this part because in every meeting the students were asked to list the questions and predict the concern of the passage. In order to be more understood to the passage they took turns to their friends in questioning and answering session. Among the four part of reading test (Multiple choice, matching headings, and Yes/No Not Given and Gap filling) the students got the lower progress in part 4. Furthermore, it can be seen that the more progress in cycle 2 rather than cycle I that happened because the more exercise given in cycle 2 rather than cycle $\mathrm{I}$.

\section{Discussion}

The data obtained in cycle I indicated that students gave positive responses in learning reading through reciprocal questioning. The improvement of the students' score was supported by the comparison of the means of tests and the result of the interview. In addition, it can be seen that there were improvement on the students' scores in reading comprehension tests from the test I to test 3 .

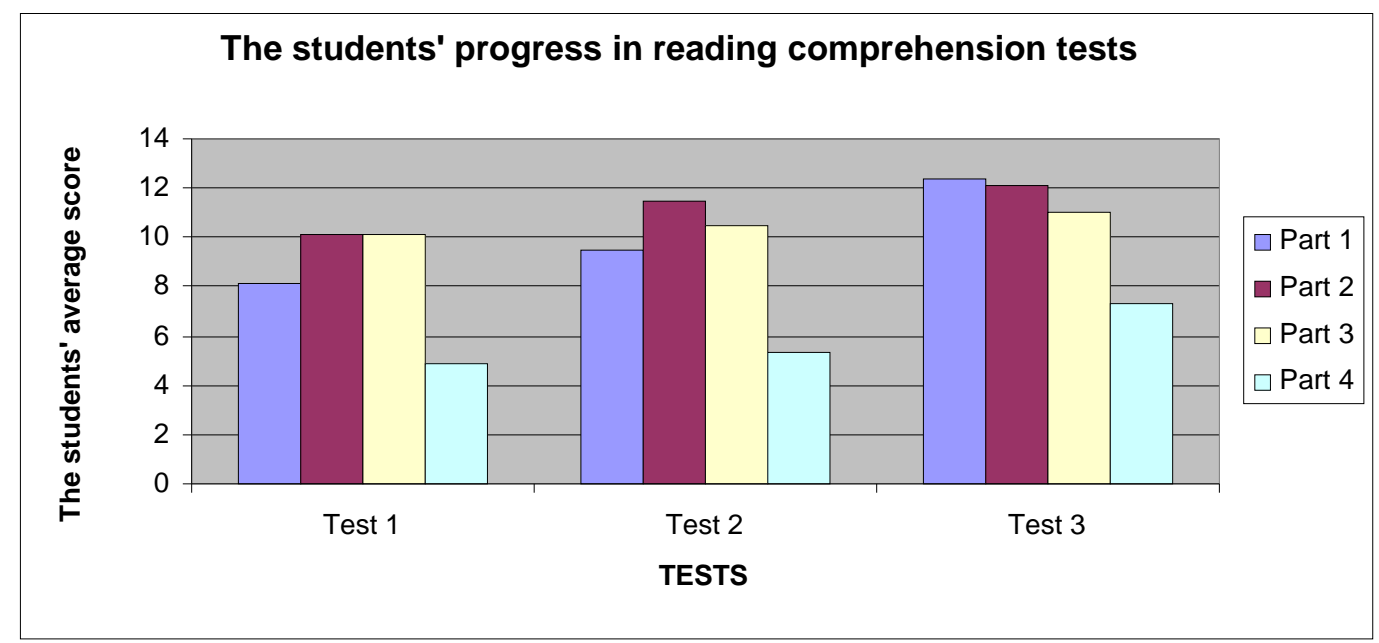

Figure I. Students' overall progress in all parts of reading comprehension tests

The chart above showed the students' average scores progress in each part of reading comprehension tests from test I to test 3. The graphic above also showed that the students got the more progress in part I (Multiple choice) while the less progress was got in part 4 (Gap filling). The students' average total score increased from test $I$ to test 3 as it was reflected on the band they achieved. While in the test I, the students' average band was less than 5 , in test 3 it became 5 and then rose above 5 . It indicates the students' improvement in 
reading comprehension after the treatment given. Besides that, based on the result of interview and field notes, it was also shown that the students respond positively toward the application of reciprocal questioning strategy.

Thus, based on the result of reading comprehension test, interview and field notes, it can be concluded that teaching reading by applying reciprocal questioning strategy (ReQuest) can improve students' critical reading ability. Furthermore, based on the result of interview, the students' confessed that among the four part of reading comprehension tests which was adopted from IELTS test, part I (Multiple choice) was the easiest part of the test while part 4 (Gap filling) was the most difficult.

\section{Conclusion}

Based on the result of the research, it can be concluded that based on the result of reading test, the application of Reciprocal Question strategy significantly improves the critical reading ability of the students. Based on the description of the filed notes, the students become more active in the learning processes. It is influenced by the activities in Reciprocal Question learning processes to develop students' ability in creating Reciprocal Question. From the result of the interview, the students argue that Reciprocal Question strategy helps them in understanding text. The result of the research reveals that the multiple choice section is easier than gap filling section for the students. Furthermore, the background knowledge and vocabularies the students have taken part in understanding the passages.

Based on the findings, discussion, and conclusion, the researcher would like to propose some suggestions. For English lecturers/teachers, in order to enhance the students' motivation in reading an academic passage, it is suggested to explain the importance of critical reading and scaffold them to implement the strategies in reading. For further research, it is expected that the strategy can be applied in various lectures and for larger participants.

\section{References}

Fisher, D. \& Frey, N. (2012). Improving adolescent literacy: Content area strategies that work. Boston: Pearson

Lika, M. (20I7). Teaching reading comprehension strategies. Academic Journal of Business, Administration, Law and Social Sciences, 3(I)

Muijselaar, M., Swart, N., Steenbeek-Planting, E., Droop, M., Verhoeven, L \& de Jong, P. (2017). Developmental Relations Between Reading Comprehension and Reading Strategies. Scientific Studies of Reading. Retrieved from http://www.tandfonline.com/action/journallnformation?journalCode=hssr20

Mason, L.H. (2004). Explicit Self-Regulated Strategy Development Versus Reciprocal Questioning: Effects on Expository Reading Comprehension Among Struggling Readers. Journal of Educational Psychology, 96(2), 283-296

Ulusoy, M. \& Dedeoglu, H. (20II). Content area Reading and Writing: Practices and Beliefs. Australian Journal of Teacher Education, 36(4), I-I7

Urlaub, P. (2013). Questioning the Text: Advancing Literary Reading in the Second Language Through Web Based Strategy Training. Foreign Language Annals, 46(3), 508-52I.

Vacca, R., Vacca, J., \& Mraz, M. (20II). Content area reading: Literacy and learning across the curriculum. Boston: Pearson.

Wallace, M.J. (1998). Action Research for Language Teachers. United Kingdom. Cambridge University Press. 